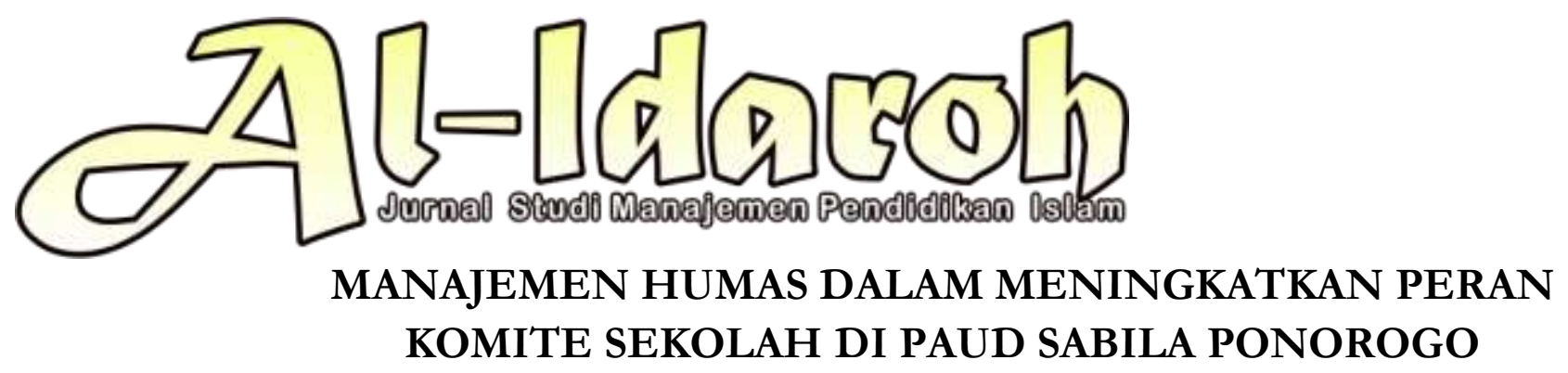

Wilis Werdiningsih

IAIN Ponorogo

Email: werdiningsih@iainponorogo.ac.id

\begin{abstract}
School and community are two inseparable things. The community needs schools to educate their children, while schools need the community to support their vision and mission. Therefore the management of school relations with the community (public relations) is an effort of the school to increase good cooperation between schools and the community. This study aims to analyze the implementation of public relations management in schools in increasing the role of school committees. This research uses a qualitative approach, with a type of case study. The results showed that public relations management carried out by schools properly,could increase the role of school committees. The optimal role of the school committee can be to increase effective communication between the school and the guardians of students and can support the implementation of school programs so that educational goals will be easier to achieve.
\end{abstract}

Keywords: Schools and Communities, Public Relations Management, Role of Committees

\title{
Pendahuluan
}

Orang tua memiliki tanggung jawab untuk memberikan pendidikan bagi anaknya.Di awal masa pertumbuhan anak, pada usia 0-4 tahun, umumnya pendidikan diberikan oleh orang tua. Ayah dan ibu merupakan sosok guru bagi anak-anaknya yang mengajari berbagai hal, mulai dari belajar bicara, bermain, berjalan dan melakukan kegiatan-kegiatan dalam kehidupan sehari-hari. Setelah menginjak usia 4 atau 5 tahun, orang tua barulah memperkenalkan lingkungan sekolah kepada anak. Di antara orang tua ada yang memilih untuk memasukkan anak-anak di jenjang play group terlebih dahulu, namun ada juga sebagian yang memilih untuk langsung memasukkannya di jenjang TK A. Menurut Sanapiah Faisal ada beberapa alasan orang tua menyekolahkan anaknya, yakni sekolah mempersiapkan anak untuk suatu pekerjaan, memberikan keterampilan dasar, membuka kesempatan memperbaiki nasib, menyediakan tenaga pembangunan, membantu memecahkan masalah sosial, 


\section{Manajemen Humas dalam Meningkatkan Peran Komite Sekolah di PAUD Sabila Ponorogo}

mentransmisikan budaya, membentuk manusia sosial dan merupakan alat mentransformasi kebudayaan. ${ }^{1}$

Setelah seorang anak memasuki jenjang sekolah, maka orang tua dan sekolah sama-sama memiliki tanggung jawab dalam pendidikan anak.Sekolah dan keluarga harus menjalin komunikasi yang baik sehingga memiliki kesamaan visi dalam mengajarkan ilmu pengetahuan dan menanamkan akhlak yang terpuji.Sekolah tidak bisa melakukan kegiatan pendidikan dengan mengabaikan peran orang tua, sebab sebagian besar waktu anak berada di rumah.Oleh sebab itu harus ada keseimbangan antara pendidikan yang diberikan oleh guru di sekolah dan orang tua di rumah. Sebagaimana yang disampaikan oleh Kang Maman, pendiri sekolah Alam di Solo bahwa sekolah menanamkan berbagai kebiasaan baik kepada anak, sementara orang tua di rumah harus merawatnya dengan menyiram dan memupuknya bukan menebangnya. ${ }^{2}$ Melalui komunikasi yang baik antara sekolah dan keluarga, maka tujuan mendidik anak menjadi seseorang yang cakap dalam ilmu pengetahuan dan baik dalam perilaku akan terwujud.

Dalam upaya menjalin komunikasi yang baik antara orang tua dengan sekolah, sekolah perlu melakukan manajemen hubungan sekolah dengan masyarakat (humas) dengan baik. Manajemen humas dipahami sebagai rangkaian kegiatan pengelolaan yang berkaitan dengan kegiatan menjalin hubungan yang baik antara lembaga pendidikan dengan masyarakat (orangtua siswa), yang dimaksudkan untuk menunjang proses belajar mengajar di lembaga pendidikan yang bersangkutan. ${ }^{3}$ Manajemen humas yang berjalan dengan baik dapat meningkatkan pemahaman orang tua akan pentingnya peran orang tua dalam pendidikan anak, termasuk mendapatkan dukungan dari orang tua baik moril maupun materil.

PAUD Sabila merupakan salah satu sekolah alam yang berada di Ponorogo.Berdasarkan hasil observasi, sekolah ini melaksanakan manajemen humas dengan melibatkan secara aktif orang tua siswa, dalam berbagai kegiatan di sekolah.Sekolah selalu melakukan musyawarah dengan komite pada setiap kegiatan yang akan dilaksanakan. Selain itu dalam berbagai kesempatan, pihak sekolah

${ }^{1}$ Kompri, Manajemen Pendidikan 2 (Bandung: Alfabeta, 2014), 267.

${ }^{2}$ Kang Maman, wawancara, Ponorogo, 15 Nopember 2019.

${ }^{3}$ Mohamad Mustari, Manajemen Pendidikan (Jakarta: PT Raja Grafindo Persada, 2014), 149. 
memberdayakan peran wali murid untuk mengambil bagian dalam mengelola kegiatan sekolah.Maka dalam penelitian ini, peneliti tertarik untuk melakukan penelitian secara lebih mendalam tentang pelaksanaan manajemen humas dalam meningkatkan peran komite sekolah di PAUD Sabila Ponorogo.

\section{Metode Penelitian}

Pendekatan penelitian kualitatif digunakan dalam penelitian ini dengan jenis studi kasus.Lokasi penelitian di PAUD Sabila yang berada di jalan Anoman, Ponorogo.Sumber data langsung penelitian di lapangan terkumpul dengan natural setting atau latar alami.Sumber data utama yang digunakan dalam penelitian ini adalah kata-kata dan tindakan, sementara selebihnya adalah bersifat tambahan seperti dokumendanlainnya pada proses kegiatan sekolah di PAUD Sabila. Teknik pengambilan datadilakukan melalui teknik observasi, wawancara dan dokumentasi. Analisis data yang dilakukan meliputi reduksi data, penyajian data, display data, penarikan kesimpulan dan pelaksanaan verifikasi. Teknik tersebut sesuai dengan komponen yang digambarkan oleh Huberman dan Miles,yakni reduksi data, memaparkan data,menyimpulkan dan memverifikasi data. ${ }^{4}$ Pengecekan keabsahan data antar sumber data yang ada, antar teknik pengumpulan data penelitian dan antar pengumpul data pada penelitian ini menggunakan triangulation atau teknik triangulasi data, yang mencakup triangulasi sumber, triangulasi metode, triangulasi teori, pengecekan kebenaran informasi (referencial adequacy checks), mendiskusikan penelitian (peer debriefing), memperpanjangwaktu penelitian (prolonged engagement), transferabilitas atau transferability, dependabilitasatau dependability dan konfirmabilitas atau confirmability. ${ }^{5}$

\section{Pembahasan}

\section{A. Manajemen Humas}

Kata manajemen diadopsi dari bahasa Latin yakni dari kata mano yang berarti "tangan", yang berubah menjadi manus sehingga memiliki arti“bekerja berkali-kali dengan menggunakan tangan". Selanjutnya kata itu mendapatkan

${ }^{4}$ Miles and Huberman, Analisis Data Kualitatif (Bandung: PT Remaja Rosdakarya, 1992), 3. 5Purbayu Budi Santosa, Paradigma Penelitian Kualitatif (Semarang: Undip, 2010), 16. 


\section{Manajemen Humas dalam Meningkatkan Peran Komite Sekolah di PAUD Sabila Ponorogo}

imbuhanagere yang berarti "melakukan sesuatu" sehingga menjadi managiare yang berarti "melakukan sesuatu berkali-kali dengan menggunakan tangan".Secara semantis, kata manajemen yang umum digunakan berasal dari kata kerja to manage yang berarti mengurus, mengatur, mengemudikan, mengendalikan, menangani, mengelola, menyelenggarakan, menjalankan, melaksanakan dan memimpin. ${ }^{6}$ Sementara itu, dalam bukunya, Morissan menjelaskan secara bahasa manajemen berarti memimpin, menangani, mengatur, atau membimbing. Sedangkan secara istilah manajemen memiliki pengertian sebuah proses yang khas dan terdiri dari tindakan-tindakan seperti perencanaan, pengorganisasian, pelaksanaan dan pengawasan yang dilakukan untuk menentukan serta mencapai sasaran-sasaran yang telah ditetapkan melalui sumber daya manusia dan sumbersumber lainnya. $^{7}$

Selanjutnya secara etimologis, hubungan masyarakat (humas) diterjemahkan dari perkataan bahasa Inggris "public relation", yang berarti hubungan sekolah dengan masyarakat.Public relation dimaknai sebagai hubungan timbal balik antara suatu organisasi (sekolah) dengan masyarakat.Jadi, manajemen humas atau public relations merupakan serangkaian kegiatan komunikasi dua arah antara sekolah dengan masyarakat untuk melakukan kegiatan perencanaan, pengorganisasian, pelaksanaan serta evaluasi dalam usaha pencapaian tujuan pendidikan bagi peserta didik. $^{8}$

Masyarakat merupakan sistem sosial dalam lingkup yang lebih besar, sementara sekolah merupakan bagian integral dari sistem sosial tersebut. Kualitas sumber daya manusia pada suatu daerah tidak hanya bergantung pada upaya-upaya yang dilakukan sekolah, akantetapi tingkat partisipasi masyarakat terhadap pendidikan juga memiliki pengaruh yang besar. Maju mundurnya sekolah di suatu daerah juga merupakan tanggung jawab bersama masyarakat setempat.Oleh sebab itu bukan hanya pihak sekolah dalam hal ini kepala sekolah dan dewan guru yang memikirkan maju mundurnya sekolah, tetapi masyarakat setempat harus terlibat

'Imam Machali dan Ara Hidayat, The Handbook Of Education Management (Jakarta: Prenadamedia Group, 2016), 1.

${ }^{7}$ Morissan, Manajemen Public Relations (Jakarta: Kencana Prenada Media Group, 2008), 5.

${ }^{8}$ Rosady Ruslan, Manejemen Public Relations \& Media Komunikasi (Jakarta: Rajawali Pers, 2008), 31. 
pula dalam memikirkan mutu pendidikan di sekolah. ${ }^{9}$ Dengan demikian, kegiatan hubungan sekolah dan masyarakat harus bisa dikelola dengan baikagar bisa mewujudkan pendidikan yang maju dan dapat dirasakan manfaatnya utamanya oleh peserta didik.

Hal mendasar dari terjalinnya hubungan sekolah dan masyarakat adalah untuk meningkatkan keterlibatan, kepedulian, kepemilikan, dan dukungan dari masyarakat terutama dukungan moral dan finansial. ${ }^{10}$ Keberadaan humas dalam suatu lembaga atau instansi dapat menjadi jembatan penghubung antara instansi dengan publiknya. ${ }^{11}$ Secara terperinci pentingnya hubungan masyarakat dan sekolah antara lain: ${ }^{12}$

1. Sekolah adalah bagian yang integral dari masyarakat, ia bukan lembaga yang terpisah dari masyarakat.

2. Masyarakat memiliki pengaruh terhadap hak hidup dan kelangsungan hidup sekolah.

3. Pelayanan dalam bidang pendidikan merupakan fungsi utama sekolah sebagai sebuah lembaga sosial.

4. Kemajuan sekolah dan kemajuan masyarakat saling berkorelasi, keduanya saling membutuhkan.

5. Berdirinya sekolah karena masyarakat membutuhkannya, sehingga masyarakat adalah pemilik sekolah.

Dari uraian tersebut dapat dipahami bahwa antara sekolah dengan masyarakat baik secara langsung maupun tidak langsung memiliki hubungan yang harus dijalin dengan baik, sebab kedua komponen tersebut memiliki kepentingan yang sama, yakni memberikan pendidikan yang terbaik bagi peserta didik.

Secara umum tujuan manajemen humas adalah untuk memberikan informasi kepada masyarakat terkait kegiatan yang diikuti peserta didik di sekolah.Sekaligus memberikan informasi semua program yang direncanakan

\footnotetext{
${ }^{9}$ Eka Prihatin, Teori Administrasi Pendidikan (Bandung: Alfabeta, 2011), 84.

${ }^{10}$ Rohiat, Manajemen Sekolah Teori Dasar Dan Praktik (Bandung: PT Refika Aditama, 2012), 67.

${ }^{11}$ Qoimah Qoimah, "Membangun Pelayanan Publik yang Prima : Strategi Manajemen Humas dalam Penyampaian Program Unggulan di Lembaga Pendidikan,” Islamic Management: Jurnal Manajemen Pendidikan Islam 1, no. 2 (August 1, 2018): 193

${ }^{12}$ Ngalim Purwanto, Administrasi Dan Supervisi Pendidikan (Bandung: PT Remaja Rosdakarya, 1999), 188.
} 


\section{Manajemen Humas dalam Meningkatkan Peran Komite Sekolah di PAUD Sabila Ponorogo}

sekolah untuk diikuti peserta didik.Dengan informasi yang diberikan tersebut, besar harapan dari pihak sekolah untuk mendapatkan dukungan penuh dari wali murid, baik dukungan moril maupun materil. Dengan dukungan tersebut maka tujuan dari lembaga pendidikan yang tertuang ke dalam visinya akan lebih mudah untuk tercapai.

Secara lebih terperinci, mengenai tujuan diselenggarakannya hubungan sekolah dengan masyarakat, Mulyono menguraikannya sebagai berikut: ${ }^{13}$ a). Mengenalkan kepada masyarakat tentang pentingnya sekolah, b).Memperoleh bantuan dan dukungan moral maupun finansial yang diperlukan bagi pengembangan sekolah, c). Memberikan informasi kepada masyarakat tentang inti dan pelaksanaan program sekolah, d). Memperkaya atau memperluas program sekolah sesuai dengan perkembangan dan kebutuhan masyarakat, e). Mengembangkan kerja sama yang lebih erat antara keluarga dan sekolah dalam mendidik anak-anak.

Sementara itu, tugas utama humas adalah: ${ }^{14}$ a). Membuat publikasi tentang keadaan pendidikan dan pengajaran di sekolah dan menginformasikan prestasi serta hal lain yang berkaitan dengan kegiatan anak di sekolah, b). Menyebarkan informasi tentang keutamaan sekolah kepada masyarakat luas, c). Membina hubungan baik dengan masyarakat dan kelembagaan masyarakat yang ada. d). Menumbuhkan dorongan dari masyarakat terhadap pendidikan dan pengajaran yang diselenggarakan, e). Melayani kepentingan masyarakat terutama bagi orang tua peserta didik tentang berbagai urusan dan informasi yang berkaitan dengan kegiatan sekolah putra-putrinya.

Adapun tahapan-tahapan dalam manajemen humas meliputi hal-hal sebagai berikut: ${ }^{15}$

a. Perencanaan (planning) mencakup penerapan tujuan atau target yang hendak dicapai, penentuan aturan dan prosedur, serta penentuan segala hal yang berkaitan dengan prediksi terhadap apa yang akan dilakukan.

\footnotetext{
${ }^{13}$ Mulyono, Manajemen Administrasi Dan Organisasi Pendidikan. (Yogyakarta: Ar Ruzz Media, 2008), 212. ${ }^{14}$ Kompri, Manajemen Pendidikean 2, 281.

${ }^{15}$ Mustari, Manajemen Pendidikan, 150.
} 
b. Pengorganisasian (organizing) mencakup pengaturan dan pembagian wewenang atau tugas bagi anggota dan sumber daya yang dibutuhkan sehingga memudahkan dalam pemantauan kerja anggota.

c. Pengoordinasian(coordinating) mencakup pengaturan struktur kepanitiaan, pendelegasian kerja masing-masing bagian, upaya sinkronisasi kerja antar bagian dan penyusunan alokasi anggaran untuk masing-masing bagian.

d. Pengkomunikasian (communicating) mencakup penyampaian rencana program kepada publik internal dan eksternal sehingga terjadi kesamaan pemahaman tujuan pendidikan yang hendak dicapai.

e. Pengawasan (controlling) merupakan kontrol atas jalannya pelaksanaan kegiatan. Tanpa adanya kontrol atas program, kesinambungan antar tahapan tidak dapat berlangsung dengan baik.

f. Pengevaluasian (evaluating) merupakan penilaian terhadap hasil jalannya kegiatan, apakah perlu dihentikan atau dilanjutkan dengan modifikasi tertentu.

g. Pemodifikasian (modificating) merupakan kegiatan pembaruan atau revisi kegiatan berdasarkan hasil evaluasi.

\section{B. Prinsip-Prinsip Manajemen Humas}

Sekolah harus berupaya untuk menjaga hubungan baik dengan masyarakat dan seyogyanya memberikan pemahaman kepada masyarakat akan pentingnya komunikasi dua arah antara sekolah dengan masyarakat. Adapun prinsip- prinsip yang dapat dijadikan pedoman dalam membangun hubungan antara sekolah dan masyarakat, yaitu sebagai berikut: ${ }^{16}$

a. Visi dan Tujuan yang Sama

Hubungan sekolah dan masyarakat perlu dibangun dalam visi dan tujuan yang sama, sehingga antara sekolah dan kepentingan masyarakat dapat saling bersinergis.

b. Bahasa yang Lugas

Hubungan sekolah dan masyarakat perlu dibangun dalam bahasa yang lugas, sehingga masyarakat akan lebih memahami segala sesuatu yang dibutuhkan

16Donni Juni Priansa, Manajemen Dan Supervisi Pendidikan (Bandung: CV Pustaka Setia, 2018), 295. 


\section{Manajemen Humas dalam Meningkatkan Peran Komite Sekolah di PAUD Sabila Ponorogo}

sekolah, begitu juga sebaliknya. Dengan demikian, komunikasi antara sekolah dan masyarkat dapat berlangsung efektif.

c. Mengingatkan

Hubungan sekolah dan masyarakat perlu dibangun untuk saling mengingatkan sehingga antara sekolah dan masyarakat dapat saling mengawasi.

d. Hubungan Baik

Hubungan sekolah dan masyrakat perlu dibangun dalam kerangka hubungan baik, sehingga antara sekolah dan masyarkat tetap dalam keadaan yang baik.

e. Kesepahaman

Hubungan sekolah dan masyarakat perlu dibangun dalam kerangka kesepahaman sehingga ketika terjadi perselisihan antara sekolah dan masyarakat hendaknya diselesaikan dalam kerangka kesepahaman.

f. Kepentingan Bersama

Hubungan sekolah dan masyarakat perlu dibangun dalam kerangka kepentingan bersama sehingga sekolah dan masyarakat akan saling menunjang satu dengan yang lainnya.

g. Fleksibel

Hubungan sekolah dan masyarakat perlu dibangun dalam kerangka yang fleksibel, sehingga sekolah dan masyarakat akan saling menyesuaikan diri.

h. Keterpaduan

Hubungan sekolah dan masyarakat perlu dibangun dalam keterpaduan, sehingga antara kepentingan sekolah dan kebutuhan msyarakat akan saling menunjang.

i. Kesinambungan

Hubungan sekolah dan masyarakat dilakukan secara terus-menerus dalam jangka waktu yang lama, sehingga prinsip kesinambungan perlu dijaga.

j. Menyeluruh

Hubungan sekolah dan masyarakat perlu dibangun dalam banyak aspek, terutama dalam kerangka pengembangan masyarakat. 


\section{Wilis Werdiningsih}

\section{Bentuk-Bentuk Hubungan Sekolah Dengan Masyarakat}

Secara umum, Suharsimi Arikunto menjabarkan bentuk hubungan sekolah dengan masyarakat ke dalam empat bentuk yakni hubungan sekolah dengan orang tua peserta didik dan masyarakat, hubungan sekolah dengan alumni, hubungan sekolah dengan dunia usaha/dunia kerja dan hubungan sekolah dengan instansi lain. Secara terperinci bentuk hubungan tersebut sebagai berikut: ${ }^{17}$

a. Hubungan Sekolah Dengan Orang Tua dan Warga Masyarakat

1) Secara Individual:

a) Orang tua datang ke sekolah untuk berkonsultasi terkait perkembangan maupun untuk memecahkan masalah anaknya.

b) Orang tua secara sukarela datang ke sekolah untuk menyampaikan saransaran yang membangun ataupun memberikan sumbangan untuk kemajuan sekolah.

2) Secara Organisasi Melalui Badan Pembantu Penyelenggara Pendidikan (BP3). Organisasi ini akan lebih efektif bila sekolah mampu menggerakkan dan memanfaatkan potensi yang ada di kalangan para orang tua, misalnya saja:

a) Orang tua peserta didik yang memiliki profesi sebagai dokter untuk turut membantu kegiatan UKS, memberikan edukasi pada peserta didik anggota UKS bahkan mendirikan poliklinik sekolah.

b) Para insinyur untuk memberikan saran-saran dalam pembangunan sekolah.

c) Para tokoh pendidikan dan anggota masyarakat lainnya dalam upaya peningkatan mutu dan mencapai prestasi sekolah yang lebih tinggi.

d) Para pejabat dalam bidang keamanan untuk peningkatan ketahanan sekolah, seperti penyuluhan tentang narkoba dan miras.

e) Para professional, pejabat dan pengusaha lainnya yang sukarela membantu sekolah demi kepentingan anak-anaknya.

b. Hubungan Sekolah Dengan Alumni

Alumni merupakan perkumpulan peserta didik yang telah lulus dari sebuah sekolah. Sebagai alumni, seyogyanya mau untuk turut memikirkan

${ }^{17}$ Suharsimi Arikunto and Lia Yuliana, Manajemen Pendidikan (Yogyakarta: Graha Cendekia, 2015), 262. 


\section{Manajemen Humas dalam Meningkatkan Peran Komite Sekolah di PAUD Sabila Ponorogo}

kemajuan sekolah dengan memberikan masukan-masukanterkait kekurangan sekolah yang perlu dibenahi, serta upaya-upaya yang perlu dilakukan untuk perbaikan. Melalui alumni juga dapat dihimpun dana bagi peningkatan kesejahteraan guru dan karyawan maupun perbaikan pembangunan. Selain itu sekolah juga dapat mengundang para alumni untuk berbagi pengalaman sebagai motivasi para peserta didik untuk lebih bersemangat dalam menuntut ilmu dan menggapai cita-cita.

c. Hubungan Sekolah Dengan Dunia Usaha/Dunia Kerja

Dunia usaha merupakan tempat di mana peserta didik dapat mengabdikan ilmunya.Sekolah dapat menjalin hubungan baik dengan instansi dunia usaha sehingga peserta didik yang siap bekerja, utamanya untuk sekolah kejuruan dapat difasilitasi untuk mendapatkan pekerjaan sesuai dengan minat dan kompetensinya.

d. Hubungan Dengan Instansi Lain

1) Hubungan dengan sekolah lain yang dapat dibina melalui musyawarah guru mata pelajaran (MGMP) dan musyawarah kerja kepala sekolah (MKKS).

2) Hubungan dengan lembaga/badan pemerintah swasta seperti kerja sama dengan bank dalam rangka penggalakan kegiatan "gemar menabung".

Sementara itu teknik-teknik yang dapat digunakan sekolah untuk memberikan gambaran tentang sekolah kepada masyarakat, adalah sebagai berikut: ${ }^{18}$ a). Laporan kepada orang tua peserta didik melalui rapor yang diberikan setelah kegiatan pembelajaran pada kurun waktu tertentu, b). Buletin bulanan yang berisikan berbagai informasi tentang sekolah dan kegiatannya, c). Penerbitan surat kabar, d). Pameran sekolah yang merupakan ajang unjuk kreativitas anak, e). Open House, f). Kunjungan ke sekolah (school visitation), g). Kunjungan ke rumah peserta didik (bome visitation), h). Penjelasan oleh staf sekolah, i). Gambaran keadaan sekolah melalui peserta didik, j). Melalui radio dan televise, k). Laporan tahunan.

${ }^{18}$ Kompri, Manajemen Pendidikan 2, 295. 


\section{Hasil Penelitian dan Pembahasan}

\section{A. Pelaksanaan Manajemen Humas di PAUD Sabila}

PAUD Sabila berdiri pada tahun 2017.Semenjak berdiri hingga saat ini PAUD Sabila memberikan ruang bagi komite sekolah untuk berpartisipasi dalam semua kegiatan sekolah.Pada setiap tahunnya, terjadi pergantian komite.Komite dipilih secara acak oleh dewan guru yang diambil dari wali murid dengan kriteria tertentu, utamanya wali murid yang dianggap mampu dan memiliki waktu yang luang untuk ikut memikirkan kegiatan sekolah.Bersama wali murid dari siswa baru (wali murid play group) dan seluruh anggota komite sebelumnya, diadakan rapat pembentukan komite di setiap awal tahun ajaran.Ketua komite dipilih dari wali murid yang lebih lama menjadi anggota komite. Hal ini sebagaimana diungkapkan oleh bunda Nisa, salah satu dewan guru PAUD Sabila sebagai berikut: "Komite sekolah kita pilih secara acak dari wali murid yang dianggap mampu dan memiliki waktu yang luang untuk memikirkan kegiatan sekolah, karena untuk setiap kegiatan sekolah kita sering mengadakan rapat." ${ }^{19}$

Komunikasi yang efektif antara sekolah dengan komite dilakukan melalui grup whatsapp.Di grup yang beranggotakan dewan guru, pengurus yayasan dan komite sekolah tersebut, sekolah membagikan setiap informasi seputar kegiatan yang akan diadakan.Grup whatsapp merupakan wadah awal informasi mengenai kegiatan dibagikan, untuk selanjutnya dewan guru dan komite mengadakan rapat untuk mempersiapkan segala sesuatu yang diperlukan untuk kegiatan sebelum informasi tersebut disebar kepada seluruh wali murid Sabila. Hal ini sebagaimana yang disampaikan bunda Ratri sebagai berikut: "Setiap akan mengadakan kegiatan sekolah, dewan guru selalu mengadakan rapat dengan komite agar terjadi kesepakatan mengenai kegiatan yang akan diselenggarakan. Setelah itu baru informasi itu kita bagikan ke seluruh warga sekolah",20

Pada setiap kegiatan sekolah selalu dibentuk kepanitiaan.Dalam kepanitiaan ini, jumlah guru dan anggota komite seimbang. Hal ini sebagai upaya untuk memastikan kegiatan sekolah yang diselenggarakan mewakili seluruh aspirasi dari stakeholder. Beberapa kegiatan yang diadakan pada setiap tahunnya adalah kegiatan

${ }^{19}$ Anisa Cyntia Devi, guru PAUD Sabila, wawancara, Ponorogo, 2 Maret 2020.

${ }^{20}$ Ratri, guru PAUD Sabila, wawancara pribadi, Ponorogo, 5 Maret 2020. 


\section{Manajemen Humas dalam Meningkatkan Peran Komite Sekolah di PAUD Sabila Ponorogo}

culture day yang merupakan agenda tahunan pada setiap pertengahan semester genap, kegiatan di bulan Ramadhan yang mencakup kegiatan kampung Ramadhan dansafari Ramadhan, penyembelihan korban pada hari raya Idul Adha dan outbond/rekreasi di berbagai tempat pada setiap tahunnya.

Komite merupakan jembatan antara wali murid dengan pihak sekolah. Melalui komite,wali murid dapat memberikan masukan terkait hal apapun mengenai sekolah dan kegiatannya yang nantinya akan disampaikan kepada dewan guru. Dan melalui komite pula sekolah dapat mengukur sejauh mana tingkat kepuasan wali murid dari kegiatan sekolah yang telah berlangsung. Hal ini sebagaimana yang disampaikan bunda Nisa sebagai berikut: "Komite merupakan jembatan penghubung antara pihak sekolah dengan wali murid. Melalui komite sekolah tahu tentang keinginan dan harapan wali murid serta mendapatkan berbagai saran terkait program-program sekolah",21

\section{B. Manajemen Humas Dalam Peningkatan Peran Komite Sekolah}

Secara teori, tahapan manajemen humas mencakup perencanaan, pengorganisasian, pengoordinasian, pengkomunikasian, pengawasan, pengevaluasian dan pemodifikasian.Secara terperinci manajemen humas yang dilakukan PAUD Sabila sebagai berikut:

a. Perencanaan

Dalam setiap kegiatan yang akan dilaksanakan, PAUD Sabila melakukan perencanaan terlebih dahulu. Perencanaan yang telah dilakukan oleh pihak sekolah disampaikan kepada yayasan untuk mendapatkan masukan dan persetujuan, untuk selanjutnya disampaikan kepada komite untuk dibahas secara lebih terperinci terkait persiapannya dalam sebuah kegiatan rapat.Pihak komite dan pihak sekolah saling bertukar pikiran dalam mematangkan perencanaan.

b. Pengorganisasian

Setelah perencanaan matang, maka tahapan selanjutnya adalah pengorganisasian.Dalam tahapan ini, dibentuk sebuah kepanitiaan yang terdiri dari pihak sekolah dan komite dengan jumlah yang seimbang.Dalam kepanitian

21 Anisa Cyntia Devi, guru PAUD Sabila, wawancara, Ponorogo, 2 Maret 2020 
dibentuk seksi-seksi sesuai dengan tanggung jawab masing-masing dan selanjutnya anggota dibagi ke dalam tiap seksi.

c. Pengoordinasian

Pada pra pelaksanaan dan pada saat pelaksanaan, anggota kepanitian melakukan koordinasi sehingga persiapan dan pelaksanaan dapat berjalan lancar.Koordinasi tidak hanya bersifat langsung namun juga tidak langsung dengan memanfaatkan grup whatsapp.

d. Pengkomunikasian

Seluruh kegiatan persiapan dan pelaksanaan kegiatan dikomunikasikan kepada wali murid sebagai bentuk transparansi dan memberikan ruang bagi seluruh wali murid untuk memberikan kritik dan saran, baik melalui komite maupun langsung kepada dewan guru.

e. Pengawasan

Pengawasan dilakukan oleh pihak yayasan selaku penanggung jawab semua kegiatan di sekolah.Pengawasan ini dilakukan untuk memastikan semua kegiatan sekolah berjalan sesuai dengan perencanaan.

f. Pengevaluasian

Pada akhir setiap kegiatan dilakukan kegiatan evaluasi untuk melihat sejauh mana keberhasilan dari kegiatan yang telah dilaksanakan.Hasil evaluasi ini dijadikan bahan perbaikan untuk kegiatan di waktu mendatang.

g. Pemodifikasian

Hasil evaluasi dijadikan dasar untuk melakukan perbaikan. Sehingga kesalahan ataupun kekurangan pada satu kegiatan, tidak akan terjadi lagi pada kegiatan berikutnya.

\section{Peran Komite Dalam Kegiatan Sekolah}

Komite merupakan jembatan penghubung komunikasi antara sekolah dengan wali murid. Melalui komite seluruh wali murid dapat memberikan masukan terkait program sekolah yang sedang berjalan maupun kegiatan sekolah yang akan diadakan. Tidak hanya menampung aspirasi dari wali murid, komite juga sebagai penghubung agenda kegiatan yang akan dilaksanakan sekolah sehingga kegiatan tersebut mendapatkan tanggapan dari wali murid secara umum, termasuk tanggapan dari anggota komite. Sehingga setiap kegiatan yang 


\section{Manajemen Humas dalam Meningkatkan Peran Komite Sekolah di PAUD Sabila Ponorogo}

diselenggarakan di PAUD Sabila merupakan hasil kesepakatan dari guru dan komite. Hal ini sebagaimana yang disampaikan oleh Retno, anggota komite dari kelas play group sebagai berikut: "Kita sebagai anggota komite selalu diajak rapat oleh guru untuk membahas kegiatan yang akan dilaksanakan di sekolah.,"22

Secara umum, komite sekolah melakukan dua bentuk komunikasi, yakni: Pertama, Komunikasi eksternal adalah komunikasi pihak komite dengan dewan guru dan juga pengurus yayasan.Komunikasi ini mencakup pemberian kritik dan saran dari anggota komite maupun penyampaian masukan dari wali murid secara keseluruhan.Melalui komunikasi ini pula, pihak sekolah memberikan informasi terkait semua kegiatan sekolah kepada anggota komite. Kedua, Komunikasi internal adalah komunikasi anggota komite dengan seluruh wali murid PAUD Sabila.Komunikasi ini dilakukan baik secara formal dalam rapat-rapat kecil yang diadakan oleh komite sendiri maupun secara non formal pada saat bertemu dalam satu forum antar wali murid.Melalui komunikasi ini, anggota komite sekolah dapat menampung aspirasi dari seluruh wali murid PAUD Sabila.

\section{Kesimpulan}

PAUD Sabila merupakan salah satu sekolah yang telah melaksanakan manajemen humas dengan melibatkan secara aktif orang tua siswa dalam berbagai kegiatan di sekolah.Sekolah berupaya sedemikian rupa untuk menjalin komunikasi yang baik dengan wali murid. Selain itu, sekolah juga melakukan musyawarah dengan anggota komite sekolah terkait semua kegiatan yang akan diadakan sekolah. Komunikasi yang efektif antara sekolah dengan anggota komite dilakukan melalui grup whatsapp untuk selanjutnya diadakan rapat yang membahas secara terperinci persiapan kegiatan sekolah. Dalam setiap kepanitiaan kegiatan sekolah, guru dan komite berbagi peran dengan jumlah yang seimbang dalam kepanitiaan tersebut.Selain itu komite sekolah juga secara aktif melakukan komunikasi eksternal maupun internal.Melalui komunikasi ini diharapkan segala sesuatu yang berkaitan dengan kegiatan sekolah dapat dibicarakan bersama antara guru dan wali murid sehingga kegiatan dapat berjalan lancar dan bermanfaat untuk anak.Selain itu melalui

22 Retno, Anggota Komite PAUD Sabila, wawancara, Ponorogo 7 Maret 2020. 
komunikasi yang efektif, pendampingan terhadap pendidikan anak bisa lebih maksimal.

\section{Daftar Rujukan}

Arikunto, Suharsimi. 2015. and Lia Yuliana. Manajemen Pendidikan, Yogyakarta: Graha Cendekia.

Huberman, Miles and. 1992. Analisis Data Kualitatif, Bandung: PT Remaja Rosdakarya.

Kompri. 2014. Manajemen Pendidikan 2. Bandung: Alfabeta.

Machali dan Ara Hidayat, Imam. 2016. The Handbook Of Education Management, Jakarta: Prenadamedia Group.

Morissan. 2008. Manajemen Public Relations, Jakarta: Kencana Prenada Media Group.

Mulyono. 2008. Manajemen Administrasi Dan Organisasi Pendidikan, Yogyakarta: Ar Ruzz Media.

Mustari, Mohamad. 2014. Manajemen Pendidikan, Jakarta: PT Raja Grafindo Persada.

Priansa, Donni Juni. 2018. Manajemen Dan Supervisi Pendidikan. Bandung: Cv Pustaka Setia.

Prihatin, Eka. 2011. Teori Administrasi Pendidikan, Bandung: Alfabeta.

Purwanto, Ngalim. 1999. Administrasi Dan Supervisi Pendidikan, Bandung: PT Remaja Rosdakarya

Qoimah, Qoimah. 2018. "Membangun Pelayanan Publik yang Prima: Strategi Manajemen Humas dalam Penyampaian Program Unggulan di Lembaga Pendidikan”, Islamic Management: Jurnal Manajemen Pendidikan Islam 1, no. 2.

Rohiat. 2012. Manajemen Sekolah Teori Dasar Dan Praktik, Bandung: PT Refika Aditama.

Ruslan, Rosady. 2008. Manejemen Public Relations \& Media Komunikasi. Jakarta: Rajawali Pers.

Santosa, Purbayu Budi. 2010. Paradigma Penelitian Kualitatif. Semarang: Undip. 